Article

\title{
Generation Y's Sustainable Purchasing Intention of Green Personal Care Products
}

\author{
Massoud Moslehpour 1,2,*(D), Panita Chaiyapruk ${ }^{1}$, Sahand Faez ${ }^{3,4}$ and Wing-Keung Wong ${ }^{5,6,7}$ (D) \\ 1 Department of Business Administration, Asia University, Taichung City 41354, Taiwan; \\ c.panita25@hotmail.com \\ 2 Department of Management, California State University, San Bernardino, CA 92407, USA \\ 3 Graduate Institute of International Politics, National Chung Hsing University, Taichung City 402, Taiwan; \\ d108022006@mail.nchu.edu.tw \\ 4 Faculty of Economics, University of Mazandaran, Babolsar 4741613534, Iran \\ 5 Department of Finance, Fintech \& Blockchain Research Center, and Big Data Research Center, Asia University, \\ Taichung City 41354, Taiwan; wong@asia.edu.tw \\ 6 Department of Medical Research, China Medical University Hospital, Taichung City 40447, Taiwan \\ 7 Department of Economics and Finance, Hang Seng University of Hong Kong, Siu Lek Yuen, \\ Hong Kong 41354, China \\ * Correspondence: writetodrm@gmail.com
}

Citation: Moslehpour, M.;

Chaiyapruk, P.; Faez, S.; Wong, W.-K.

Generation Y's Sustainable

Purchasing Intention of Green

Personal Care Products. Sustainability

2021, 13, 13385. https://doi.org/

$10.3390 /$ su132313385

Academic Editor: Antonino Galati

Received: 2 November 2021

Accepted: 26 November 2021

Published: 3 December 2021

Publisher's Note: MDPI stays neutral with regard to jurisdictional claims in published maps and institutional affiliations.

Copyright: (C) 2021 by the authors. Licensee MDPI, Basel, Switzerland. This article is an open access article distributed under the terms and conditions of the Creative Commons Attribution (CC BY) license (https:// creativecommons.org/licenses/by/ $4.0 /)$.

\begin{abstract}
Global warming and depletion of the environment are more than a hunch; they are irrefutable facts. While caring for the environment seemed like a luxurious hobby twenty years ago, it has become a crucial necessity these days. However, the sustainable demand for eco-friendly products seems to be less than it should be. In other words, the consumers seem to lack the intent to purchase green products. Therefore, studies on factors affecting sustainable green purchasing intent seem to be crucial now more than ever. This study attempts to shed some light on the matter using structural equation modeling. After receiving the answers of 357 respondents from Thai Generation Y participants, the estimations reveal that attitude towards green packaging and green marketing awareness have the strongest effects on purchasing intention. On the other hand, environmental concern seems to have the weakest effect on purchasing intention. The findings suggest that the producers must pay more attention to packaging and other novel forms of marketing to increase the customers' intent for purchasing green products.
\end{abstract}

Keywords: green purchasing intention; green personal care products; green marketing awareness; green packaging

\section{Introduction}

Following the considerable increase in consumption over the past ten years, natural resources have taken a massive toll. Moreover, nature itself has been affected by this. For instance, the Earth's temperature has increased [1]; air and water quality have decreased [2]; and public awareness of such issues has increased as well [3,4]. In other words, while the environment's quality is decreasing, the public is increasingly becoming more aware of this depleting trend. The 2021 United Nations Climate Change Conference, more commonly referred to as COP26, is a prime example. Furthermore, consumption of eco-friendly products, also referred to as green purchasing or eco-friendly purchasing, results from such awareness [3,5].

The market for personal care products is one of the key segments of the global market, worthy of closer studies. That is because it has experienced a massive increase in scale over the past few years [6]. In 2017, the global market size for this product was estimated at $\$ 14.2$ billion, and it is expected to reach $\$ 31.7$ billion in 2025 [7]. According to a report published by the International Trade Administration in 2019 [8], Thailand is one of the key markets for personal care products with a considerable growth rate. Between 2013 and 
2019, the market for personal care products in Thailand grew around 7.2-7.9\%. Moreover, its market is expected to reach $\$ 8$ billion in 2022.

One of the defining features of the Thai people is their considerable environmental awareness, which has been quite high since 1994 [9]. Therefore, they try to increase the share of products that claim to be natural and eco-friendly in their consumption package. However, they also give weight to the price of the products they consume [10]. Nevertheless, the demand for green and organic products is increasing; and personal care products are no exception. Therefore, many firms push to adopt green practices into their businesses [11]. As a result, marketing emphasizing product greenness has also become an important factor in the current markets.

According to the latest reports published in Thailand [12], The share of Generation $Y$ in the country's population is more than 40 percent. Generation $Y$ encompasses those born between 1980 and 2000, making them between 18 to 40 years of age at the moment. Amongst their characteristics are their comfort with technology, self-awareness, and concern for environmental issues [12]. Therefore, this generation seems to be a unique candidate for studying the factors affecting purchasing intentions.

A deeper understanding of this generation's purchasing intentions, given its emphasis on eco-friendliness and its considerable share in the market, is crucial for a successful marketing strategy in any market; let alone the market which has shown massive growth over the past decade, i.e., the market for personal care products. Therefore, this study has been conducted in order to answer the following question:

RQ: Does environmental awareness affect Generation Y's purchasing intention for personal care products in Thailand?

In order to answer this question, in this study, the environmental awareness of Generation $\mathrm{Y}$ is divided into environmental concern (EC), environmental knowledge (EK), green marketing awareness (GMA), green price sensitivity (GDP) and attitude towards green packaging (ATGP). Several previous studies have considered one or two of these factors when analyzing their effects on purchasing intention. For instance, Anastasios and Anastasios [13] have studied the effects of EC and EK on green consumption. Furthermore, Noorhazila et al. [13] show the importance of EK in explaining consumer behavior. Similar arguments can be found regarding the other factors [14-16].

Despite the existence of several studies on factors affecting consumption based on the goods' eco-friendliness $[5,7,11]$ there is still room for analyzing the combined effects of these factors on purchasing intentions of specific age groups such as Generation $Y$ for a specific product such as personal care products. Therefore, the commonalities of this study with the existing literature, notwithstanding, could be considered a new step towards a better understanding of a sustainable market for personal care products.

In the remaining sections of this study, first, by discussing the existing literature and theoretical debates, the study's conceptual framework will be presented. Next, based on the existing body of literature, the main hypotheses for the study are extracted. Then, the methodology through which the data in this study are assessed will be introduced. Finally, after analyzing the results of the model's estimation, conclusions and discussions will be presented.

\section{Theoretical Framework}

This section will discuss the concept of green consumption based on the existing body of literature. The purpose of this section is to draw a theoretical map of green consumption and the key factors affecting it. The argument will commence with the discussion of traditional consumption theories; the basics of these theories will then be combined with the features of the theory of planned behavior [17] and the value attitude-behavior hierarchy model [18] from the literature of social psychology; the argument will then evolve into the role of consumer's behavior concerning environmental concerns. Eventually, a theoretical framework will be drawn to build the foundation for the conceptual framework. 
The analysis of consumption and the factors affecting it began as an endeavor among microeconomists under the banner of consumer theory [19]. They argue that consumption is defined by the consumer's income and the prices of the products (the budget constraint) on the one hand and the consumer's preferences for certain products (utility function) on the other hand. The former covers one's ability to procure certain volumes of certain products; while the latter is more concerned with one's desires, intent and preferences. With the development of macroeconomics, analysis of consumption evolved further. Initially, Keynes's theory of consumption discusses the relation between income and consumption [20]. Furthermore, Modigliani's life-cycle hypothesis [21] and Duesenberry's relative income hypothesis [22] added time and peer comparison, respectively, to the analysis.

While both macroeconomics and microeconomics covered how material factors affect one's decision to consume what one consumes, the field of social psychology succeeded in expanding on the mental aspect of a consumer's decision-making process. To economists, the utility function was, and still is, a vague function following the assumptions of being complete, reflexive and transitive, and having continuity and monotonicity [19]. Reaching a more comprehensive theory of consumption requires a more detailed assessment of the consumer's decision-making process (both material and mental). The two concepts of the theory of planned behavior and the value attitude behavior hierarchy model from social psychology could aid in reaching such a theory of consumption.

The theory of planned behavior was developed by Icek Ajzen from the theory of reasoned behavior [17] in his influential work from intentions to actions: a theory of planned behavior. Based on this theory, three core concepts comprise one's behavior, attitude, subjective norms, and perceived behavioral control. These concepts affect one's intent and consequently embody one's behavior. The norms that are in play in the society combined with one's attitude towards such norms and one's comprehension of these norms will define and direct one's intentions and, in turn, his/her behavior. Norms could come from communities in terms of traditions and peer pressure, or they could be more official and less flexible such as state laws and regulations [23].

Norms and traditions are rooted in values. Furthermore, values could come from personal features and be internal; they could result from social interactions and be external. In other words, one's values could come from their perception of who they are or how they perceive themselves through the lens of the society they grew up or lived in. Starting with the work of Homer and Kahle [18], through a form of hierarchy, one's values could and would eventually affect one's behavior. Based on their findings, values are the first step in the process. Next, they affect one's attitude, which eventually shapes and affects behavior. In the literature, this process is known as the value-attitude-behavior hierarchy.

Combining the macroeconomic and microeconomic theory of consumption with the theory of planned behavior and the value-attitude-behavior hierarchy will give the following theoretical framework covering both material and mental factors that affect the consumer's behavior. An individual's income and the prices of the products comprise the material factors; values plus norms define the mental factors. Together they shape an individual's behavior. When individuals take on the role of consumers, consumption or consumer behavior is formed (Figure 1). This study intends to assess this framework for green products as the goods being consumed. The next section discusses this concept and reaches the conceptual framework and the study's hypotheses. 


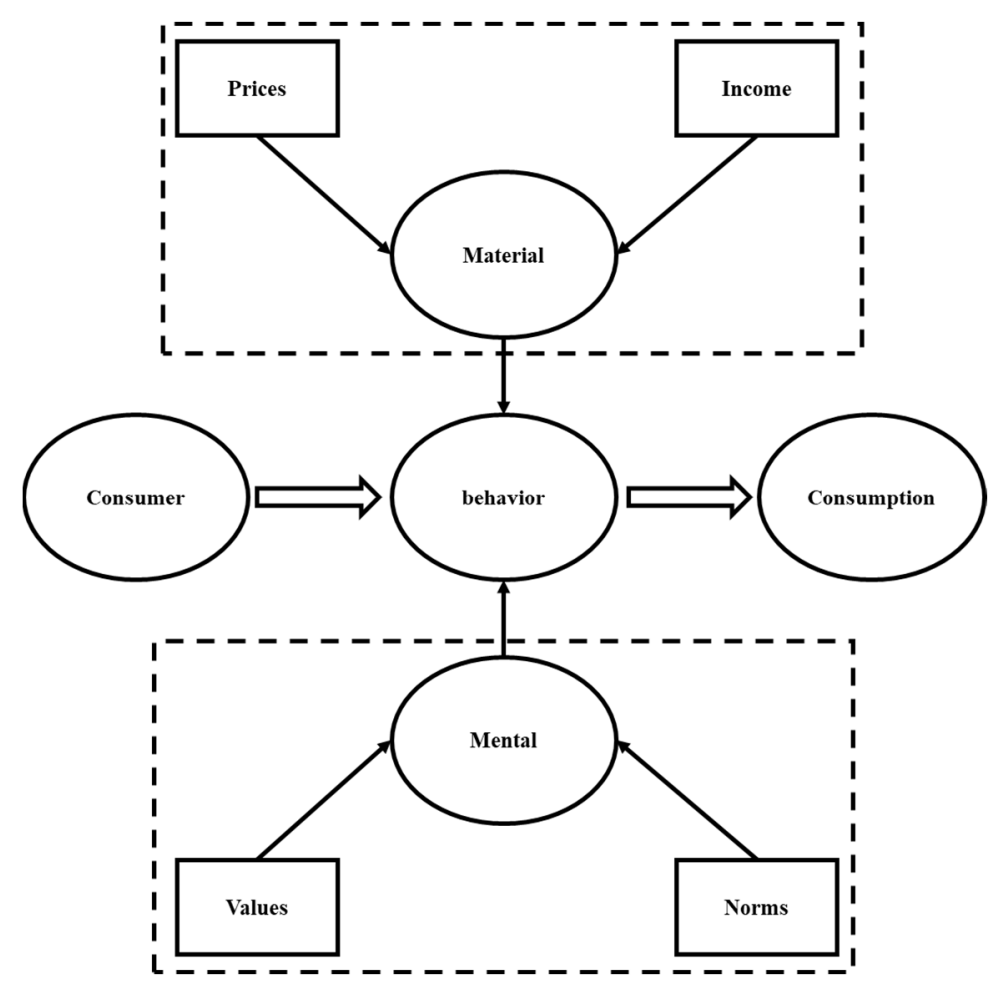

Figure 1. Schematic depiction of the theoretical arguments.

\section{Theoretical Debate and Hypotheses Development}

\subsection{Environmental Concern and Environmental Knowledge}

Environmental concern is defined as the people's realization level towards environmental issues [24]. The earth today is much more different than the earth a hundred years ago. It even has a considerable difference from what it was twenty years ago. The $\mathrm{CO}_{2}$ levels are critically high; earth temperature has drastically increased; sea levels are dangerously high. These make environmental concern is a key issue in the 21st century. It could be related to the breakage of the environment that might affect society [25]. According to previous studies, it could also be an important motivating factor for the customers' decision to buy pro-environment products $[20,26,27]$. On the other hand, environmental knowledge could be defined as people's level of understanding concerning the environment and the ecosystem [28]. According to Anastasios and Anastasios [13], environmental concern and environmental knowledge are key factors explaining green consumption.

Moreover, according to Bang et al. [29], environmental concern and environmental knowledge are significant. Therefore, it seems that having concerns towards the environment pushes the individual towards improving his/her knowledge regarding the environment. Therefore, this study hypothesizes that the sustainable correlation should come from environmental concern towards environmental knowledge. Hence, the following hypothesis is proposed.

Hypothesis 1 (H1). Environmental concern has a significant and positive influence on environmental knowledge.

\subsection{Environmental Knowledge and Attitude towards Green Packaging}

Since its invention in 1907, plastic has been a source of utility and pollution; because it takes ages before a single plastic bag could dissolve into nature. On the other hand, being one of the main ingredients in packaging, plastic pollution has become a serious issue. At the same time, such an issue has given birth to the concept of green packaging (GP), which could influence the brand's characteristics and popularity [3]. Some customers also believe GP products to have higher quality and better taste. For instance, Rajendran et al. [30] 
mentioned that GP products smell and taste better for Malaysian consumers, have more reasonable prices, and are healthier.

Furthermore, according to Noorhazila et al. [13], consumers' awareness of green packaging could be a defining factor in their attitude towards green packaging (ATGP). In other words, they may show more support for GP products if they know of their benefits for the environment. They have also shown that knowledge brings responsibility. Therefore, having environmental knowledge could affect the consumers' attitude sustainability towards green packaging. Hence, the following hypothesis is proposed.

Hypothesis 2 (H2). Environmental knowledge has a significant and positive influence on attitude towards green packaging.

\subsection{Green Marketing Awareness and Attitude towards Green Packaging}

According to the literature, green marketing increasingly emphasizes the eco-friendliness of the product being marketed [31]. One aspect of this endeavor includes modification of the supply chain to make the product eco-friendlier. However, the importance of green production notwithstanding, a firm needs to make the consumer aware of its efforts towards becoming more eco-friendly. Therefore, green marketing awareness-the firm's efforts in showing how it cares about the environment-becomes crucial.

Green marketing awareness (GMA) could be defined as green marketing through consumers' perceptions of the products they consume [15]. Consequently, packaging plays a crucial role in shaping such a perception. The products package is the first thing the customer sees. Therefore, it is the first tool at the firm's disposal to affect the customer's perception [32]. Moreover, awareness does affect attitude [15,33]. In other words, being more aware of a product's eco-friendliness would affect the customer's attitude towards the product. Hence the following hypothesis is proposed.

Hypothesis 3 (H3). Green marketing awareness has a significant and positive influence on attitude towards green packaging.

\subsection{Environmental Knowledge and Purchasing Intention}

In terms of meaning, purchasing intention (PI) refers to the consumer's likelihood to purchase a product or service [34]. In other words, PI is the feasibility and willingness of customers that plan to buy in the future [35]. Many factors affect the customer's purchasing intention. With increased attention towards the environment and how products affect it, products' eco-friendliness has joined the rank of factors affecting purchasing intention.

Above all other factors, one must possess a minimum knowledge of the product one wishes to buy before becoming intent on purchasing the product. In terms of greenness, the same argument stands. Green marketing literature suggests that a customer's environmental knowledge is expected to have considerable effects on purchasing intention $[16,35,36]$. Hence the following hypothesis is proposed.

Hypothesis 4 (H4). Environment knowledge has a significant and positive influence on purchasing intention.

\subsection{Green Price Sensitivity and Purchasing Intention}

In economics, price is the value assigned to any specific good or service. However, this is different for each person. Furthermore, as the price changes, each person's reaction to this change would also be different. In other words, each person has his/her price sensitivity [37]. This sensitivity is usually estimated by a measure called price elasticity [38].

Additionally, a consumer's price sensitivity or the product's price elasticity is affected by several factors such as local identity [39], satisfaction with the product [40], and global identity [41]. Among these, one could name eco-friendliness as a key factor [42]. Therefore, attention towards eco-friendliness could mitigate the consumer's price sensitivity, making them more acceptable towards higher prices for green products. Just as a consumer's 
price sensitivity is a logical and key influencing factor for his/her purchasing intention in general, so is green price sensitivity (GPS) for green purchasing intention. Therefore, giving more value to a product's eco-friendliness means the consumer would be willing to accept higher prices, which means the consumer would be willing to purchase the product despite its higher price. In other words, the higher one's green price sensitivity is, the higher one's green purchasing intention will be [43]. Hence, the following hypothesis is proposed.

Hypothesis 5 (H5). Green price sensitivity has a significant and positive influence on purchasing intention.

\subsection{Attitude towards Green Packaging and Purchasing Intention}

To reduce packaging pollution, many customers consume green products and consider using eco-friendly packaging. According to Prakash and Pathak [3], there is a significant and positive correlation between ATGP and PI. In other words, consumers give a great deal of attention to the product's packaging to build their intent. This claim has been tested in different environments, which have shown the same results. For instance, Auliandri et al. [44] tested the same hypothesis in Indonesia and reached the same conclusion. Hence, the following hypothesis is proposed.

Hypothesis 6 (H6). Attitude towards green packaging has a significant and positive influence on purchasing intention.

Based on the hypotheses of this study, the conceptual framework of this study is presented in Figure 2.

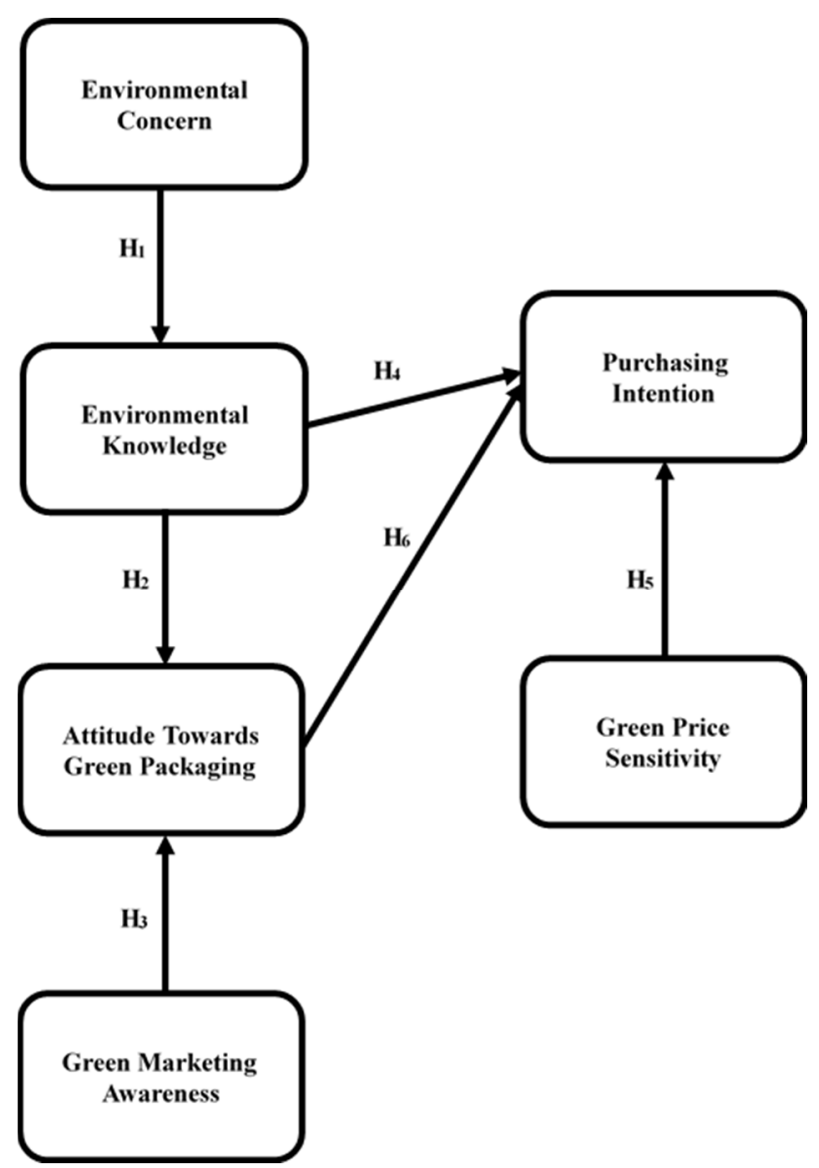

Figure 2. Conceptual hypotheses framework. 


\subsection{The Mediatory Effects}

According to the above conceptual framework, besides its direct effect on purchasing intention, environmental knowledge indirectly affects purchasing intention through attitude towards green packaging. Furthermore, environmental concern does affect purchasing intention through environmental knowledge via two routes: first through its direct effect on the purchasing intention and second through its indirect effect through attitude towards green packaging. Moreover, green marketing awareness seems to affect purchasing intention through attitude towards green packaging indirectly. Several previous studies have tested these indirect effects $[13,36,45-47]$. Hence, the following hypotheses are proposed.

Hypothesis 7 (H7). Attitude towards green packaging mediates the relationship between environmental knowledge and purchasing intention.

Hypothesis 8 (H8). Attitude towards green packaging mediates the relationship between green marketing awareness and purchasing intention.

Hypothesis 9 (H9). Environmental knowledge and attitude towards green packaging mediate the relationship between environmental concern and purchasing intention.

\section{Methodology}

\subsection{Development of the Questionnaire}

This study is based on the data acquired from a structural questionnaire that assesses each participant's attitude towards eco-friendly personal care products. The questions are based on a 5-point Likert Scale. The demographic questions aside, the questions in this questionnaire were extracted from several studies that focused on purchasing green products. Table 1 summarizes the questionnaire and the sources from which its questions are derived. As the table shows, four questions assess environmental concern, five questions assess environmental knowledge, five questions assess attitude towards green packaging, five questions assess green marketing awareness, four questions assess green price sensitivity, and four questions assess purchasing intention.

Table 1. Research Constructs and their Relative Questions.

\begin{tabular}{|c|c|c|}
\hline Variables & Item & References \\
\hline $\begin{array}{l}\text { Environmental Concern (EC) } \\
\text { The realization degree of people } \\
\text { about the ecological issues [20] }\end{array}$ & $\begin{array}{l}\text { - Humans ruin the environment. } \\
\text { - } \quad \text { Human existence depends on the nature. } \\
\text { - } \quad \text { Human interruptions are a natural cause of disasters. } \\
\text { - Nature is delicate and can easily be damaged. }\end{array}$ & {$[20,47,48]$} \\
\hline $\begin{array}{l}\text { Environmental Knowledge (EK) } \\
\text { People's understanding of the } \\
\text { environment and related problems } \\
{[20]}\end{array}$ & $\begin{array}{l}\text { - I have more understanding of recycling than others around me. } \\
\text { - I understand environmental problems. } \\
\text { - I understand how to conserve the environment. } \\
\text { - I understand the primary causes of global warming. } \\
\text { - } \quad \text { Iam are that plastic till take a long time deempese. }\end{array}$ & {$[20,28]$} \\
\hline $\begin{array}{l}\text { Attitude Towards Green Packaging } \\
\text { (ATGP) }\end{array}$ & $\begin{array}{l}\text { - I prefer buying OPCP with recyclable packaging. } \\
\text { - } \quad \text { I prefer buying OPCP that use biodegradable packaging. } \\
\text { - } \quad \text { I would buy biodegradable OPCP from a less-known company. } \\
\text { - } \quad \text { Buying OPCP with green packaging can help lower global } \\
\text { warming. } \\
\text { Buying OPCP with green packaging can reduce environmental } \\
\text { problems. }\end{array}$ & {$[3,49]$} \\
\hline
\end{tabular}


Table 1. Cont.

\begin{tabular}{|c|c|c|}
\hline Variables & Item & References \\
\hline $\begin{array}{c}\text { Green Marketing Awareness (GMA) } \\
\text { Attentiveness towards the } \\
\text { environment to achieve the } \\
\text { consumers' needs and satisfaction } \\
\text { [50] }\end{array}$ & $\begin{array}{l}\text { - } \quad \text { I prefer the store that sells OPCP with green labels. } \\
\text { - } \quad \text { I prefer the OPCP store that is set up with an eco-friendly concept. } \\
\text { - } \quad \text { Green product advertisement is informative about OPCP. } \\
\text { - } \quad \text { Green product advertisement makes me feel good toward OPCP. } \\
\text { - Green product advertisements can help the customers' decision to } \\
\text { buy OPCP. }\end{array}$ & {$[16,50]$} \\
\hline $\begin{array}{l}\text { Green Price Sensitivity (GPS) } \\
\text { The consumer's sensitivity towards } \\
\text { the premium price of the products, } \\
\text { especially green products [38] }\end{array}$ & $\begin{array}{l}\text { * When Ibuy the OPCP, the price is not important. } \\
\text { I compare the prices of OPCP before buying OPCP. } \\
\text { - I will check my budget before buying OPCP. } \\
\text { I can remember the prices of OPCP that I use in my daily life. }\end{array}$ & [39] \\
\hline $\begin{array}{l}\text { Purchasing Intention (PI) } \\
\text { The willingness of the consumer to } \\
\text { buy the product or service [27] }\end{array}$ & $\begin{array}{l}\text { - } \quad \text { I intend to buy a pro-environmental product. } \\
\text { - } \quad \text { I prioritize OPCP when shopping for personal care. } \\
\text { - } \quad \text { I would buy an OPCP in the near future. } \\
\text { - } \quad \text { I intend to buy green packaging products. }\end{array}$ & {$[3,28]$} \\
\hline
\end{tabular}

Source: Extracted from several studies (mentioned in the table). ${ }^{*}$ Strikethroughs are deleted items.

Nine items were omitted from the final analysis after further considerations using exploratory factor analysis (EFA) due to their low factor loading. This analysis method is commonly used to reduce invalid variables [51]. The remaining items all had factor loadings of more than 60 percent. Table 1 shows the items that were omitted from the final analysis. Factor Analysis (both confirmatory and exploratory) was conducted via the use of SPSS Amos 25.

\subsection{Sample and Data Collection}

The population under study in this research is Thailand's Generation Y which consists of the Thai people born between 1980 and 2000, making them between 18 to 40 years of age. The reason for choosing this population was discussed thoroughly in the previous sections. This generation is raised with technology, is also quite self-aware, and has shown considerable attention to environmental issues. According to the latest official statistics, amongst the 69.8 million people inhabiting Thailand, 44 percent belong to Generation Y [52]. Using Cochran's formula for defining the sample size [53], the sample under study in this research with a 95 percent degree of confidence would be 378. Four hundred and eight questionnaires were distributed. After further analysis and removal of the invalid responses, 357 valid subjects were gathered.

\section{Analysis of Estimation Results}

\subsection{Demographics of the Sample}

In this study, a total of 357 valid respondents among Thailand's Generation Y were collected through an online questionnaire. According to the preliminary findings, 72.5 percent (259 people) have used green care products before; 18.5 percent (66 people) were men; 49.8 percent (178 people) were younger than 25 years old; 62.5 percent (223 people) had a bachelor's degree; 34.5 percent (123 people) were students; 49.6 percent (177 people) were wage-earning employees; 35.6 percent (127 people) earned less than $\$ 500 ; 30.8$ percent (110 people) earned less than $\$ 833$ and more than $\$ 500$. In conclusion, according to the preliminary findings, the sample mostly consists of women with wage-earning jobs, bachelor's degrees, less than 25 years of age, and less than $\$ 800$ monthly income: a relatively poor and young generation with university education and a steady income. 


\subsection{Measurement Model}

In the beginning, Harman's one-factor test for common method bias (CMB) was conducted to ensure no single factor bias exists. The test is to examine the existence of a single factor bias in the model. According to this test, if the first factor in the preliminary EFA accounts for more than $50 \%$ of the total variance, using the remaining factors might result in bias [53]. Since the explained variance with a single factor $(34.51 \%)$ was less than the critical threshold $(50.00 \%)$, there is no single factor bias present in the study. Furthermore, after removing the items with factor loadings less than 60 percent ( 9 items) via the use of exploratory factor analysis (EFA), the validity and reliability of the remaining items and their relative constructs were assessed using confirmatory factor analysis (CFA). According to the findings, the model's total KMO index is 0.88 , well above the threshold. Therefore, the results from a factor analysis model would be reliable, and the sample is adequate. Furthermore, the results from the CFA model suggest a valid and reliable fit $\left(\chi^{2} / \mathrm{df}=2.17, \mathrm{GFI}=0.92, \mathrm{CFI}=0.95, \mathrm{TLI}=0.93\right.$, and RMSEA $\left.=0.06\right)$. In addition, the Cronbach's alpha for each construct is above 0.6 which indicates an acceptable level of reliability [54,55].

On the other hand, the composite reliability values for each construct vary between 0.6 and 0.8, which is well in the range Bagozzi and Yi [56] suggest as an acceptable value. Moreover, the average variance extracted (AVE) for each construct also meets the standard value Brown and Cudeck [57] suggest. Although it is less than 0.5 for two of the constructs (environmental concern and green price sensitivity), since the $C R$ values are more than 0.6 , the constructs are acceptable based on Fornell and Larcker [58]. Furthermore, although the items for EC and GPS are only two, the CR, KMO and Cronbach's alpha suggest an acceptable estimate and sample size. This claim has been supported in the literature by Winter et al. [59]. In sum, given the values reported in Table 2, the model possesses an acceptable level of reliability and validity.

Table 2. Measurement model.

\begin{tabular}{|c|c|c|c|c|c|c|}
\hline Construct & Items & $\begin{array}{l}\text { Factor } \\
\text { Loading }\end{array}$ & CR & KMO & $\begin{array}{c}\text { Cronbach } \\
\text { Alpha }\end{array}$ & AVE \\
\hline \multirow{3}{*}{$\begin{array}{c}\text { Environmental } \\
\text { Concern }\end{array}$} & EC1 & 0.61 & \multirow{3}{*}{0.636} & \multirow{3}{*}{0.5} & \multirow{3}{*}{0.62} & \multirow{3}{*}{0.469} \\
\hline & EC3 & 0.75 & & & & \\
\hline & EK1 & 0.61 & & & & \\
\hline \multirow{4}{*}{$\begin{array}{l}\text { Environmental } \\
\text { Knowledge }\end{array}$} & EK2 & 0.80 & \multirow{4}{*}{0.823} & \multirow{4}{*}{0.78} & \multirow{4}{*}{0.81} & \multirow{4}{*}{0.541} \\
\hline & EK3 & 0.80 & & & & \\
\hline & EK4 & 0.72 & & & & \\
\hline & ATGP2 & 0.72 & & & & \\
\hline Attitude Towards & ATGP3 & 0.63 & \multirow{3}{*}{0.878} & \multirow{3}{*}{0.79} & \multirow{3}{*}{0.88} & \multirow{3}{*}{0.649} \\
\hline \multirow[t]{2}{*}{ Green Packaging } & ATGP4 & 0.92 & & & & \\
\hline & ATGP5 & 0.91 & & & & \\
\hline Green Price & GPS2 & 0.76 & \multirow[b]{2}{*}{0.641} & \multirow[b]{2}{*}{0.5} & \multirow[b]{2}{*}{0.63} & \multirow[b]{2}{*}{0.474} \\
\hline Sensitivity & GPS3 & 0.61 & & & & \\
\hline \multirow{3}{*}{$\begin{array}{c}\text { Green Marketing } \\
\text { Awareness }\end{array}$} & GMA3 & 0.71 & \multirow{3}{*}{0.785} & \multirow{3}{*}{0.7} & \multirow{3}{*}{0.78} & \multirow{3}{*}{0.55} \\
\hline & GMA4 & 0.79 & & & & \\
\hline & GMA5 & 0.73 & & & & \\
\hline \multirow{3}{*}{$\begin{array}{l}\text { Purchasing } \\
\text { Intention }\end{array}$} & PI1 & 0.73 & \multirow{3}{*}{0.789} & \multirow{3}{*}{0.69} & \multirow{3}{*}{0.78} & \multirow{3}{*}{0.558} \\
\hline & PI3 & 0.66 & & & & \\
\hline & PI4 & 0.84 & & & & \\
\hline Total & & & & 0.88 & & 34.514 \\
\hline
\end{tabular}

Finally, the discriminant validity of the constructs was estimated. The results are reported in Table 3. As the figures show, cross-values for each pair of constructs are all less than 0.85 . in other words, the constructs possess discriminant validity and cannot be substituted with one another. In other words, the constructs have been chosen optimally for a structural equation model (SEM) to test the study's hypotheses. 
Table 3. Discriminant validity.

\begin{tabular}{ccccccc}
\hline Construct & EC & EK & ATT & GPS & GMA & PI \\
\hline EC & $\mathbf{0 . 6 8 5}$ & & & & & \\
EK & 0.211 & $\mathbf{0 . 7 3 5}$ & & & & \\
ATT & 0.074 & 0.391 & $\mathbf{0 . 8 0 6}$ & & & \\
GPS & 0.324 & 0.430 & 0.465 & $\mathbf{0 . 6 8 9}$ & & \\
GMA & 0.323 & 0.430 & 0.540 & 0.634 & $\mathbf{0 . 7 4 2}$ & \\
PI & 0.182 & 0.451 & 0.741 & 0.496 & 0.647 & $\mathbf{0 . 7 4 7}$ \\
\hline
\end{tabular}

Source: own calculations. The bold face diagonal is SQRT(AVE).

\subsection{Testing the Hypotheses via SEM}

After ensuring the validity and reliability of the data via EFA and CFA, the six main hypotheses and the three complementary hypotheses were tested via a structural equation model (SEM). According to the preliminary findings, the estimated SEM in this study is a good and reliable fit $\left(\chi^{2} / \mathrm{df}=2.12, \mathrm{GFI}=0.92, \mathrm{CFI}=0.90\right.$, AGFI $=0.90$, and RMSEA $\left.=0.06\right)$. Table 4 reports the results of the SEM.

Table 4. The SEM results for testing the hypotheses.

\begin{tabular}{|c|c|c|c|c|c|c|}
\hline Hypothesis & Path & \multicolumn{2}{|c|}{ Standardized Estimates $(\beta)$} & S.E. & $p$-Value & Result \\
\hline $\mathrm{H} 1$ & $\mathrm{EC} \rightarrow \mathrm{EK}$ & & $0.29 * * *$ & 0.087 & 0 & Accepted \\
\hline $\mathrm{H} 2$ & $\mathrm{EK} \rightarrow \mathrm{ATGP}$ & & $0.21^{* * *}$ & 0.081 & 0 & Accepted \\
\hline $\mathrm{H} 3$ & $\mathrm{GMA} \rightarrow \mathrm{ATGP}$ & & $0.49^{* * *}$ & 0.083 & 0 & Accepted \\
\hline $\mathrm{H} 4$ & $\mathrm{EK} \rightarrow \mathrm{PI}$ & & $0.14 * *$ & 0.062 & 0.009 & Accepted \\
\hline H5 & $\mathrm{GPS} \rightarrow \mathrm{PI}$ & & $0.26^{* * *}$ & 0.084 & 0 & Accepted \\
\hline \multirow[t]{2}{*}{ H6 } & $\mathrm{ATGP} \rightarrow \mathrm{PI}$ & & $0.60 * * *$ & 0.056 & 0 & Accepted \\
\hline & & Total & $0.45^{* *}$ & & & Accepted \\
\hline \multirow[t]{3}{*}{ H7 } & $\mathrm{EK} \rightarrow \mathrm{ATGP} \rightarrow \mathrm{PI}$ & Direct & $0.19 * *$ & & & (Partial \\
\hline & & Indirect & $0.26^{* *}$ & & & Mediation) \\
\hline & & Total & $0.65^{* *}$ & & & Accepted \\
\hline \multirow[t]{3}{*}{$\mathrm{H} 8$} & $\mathrm{GMA} \rightarrow \mathrm{ATGP} \rightarrow \mathrm{PI}$ & Direct & $0.35 * *$ & & & (Partial \\
\hline & & Indirect & $0.30 * *$ & & & Mediation) \\
\hline & & Total & $0.21 * *$ & & & Accepted \\
\hline \multirow[t]{2}{*}{ H9 } & $\mathrm{EC} \rightarrow(\mathrm{EK} \rightarrow \mathrm{ATGP}) \rightarrow \mathrm{PI}$ & Direct & 0.15 ** & & & (Partial \\
\hline & & Indirect & 0.06 ** & & & Mediation) \\
\hline
\end{tabular}

Degree of confidence: ${ }^{* * *} p<0.001,{ }^{* *} p<0.01$. Source: own calculations.

The first look at the results in Table 4 suggests that all the study's hypotheses were accepted with a $90 \%$ degree of confidence or higher. However, upon closer inspections, further information is revealed. For instance, the effect of green marketing awareness on attitude towards green packaging (0.49) is more than twice that of environmental knowledge. Furthermore, among the factors directly affecting purchasing intention, environmental knowledge has the lowest effect (0.14) while the attitude towards green packaging shows the highest effect (0.6); a value is more than four times that of environmental knowledge. Finally, among the three combined paths included in this study, the total effect of green marketing awareness on purchasing intention (0.65) has the highest effect. On the other hand, the highest indirect effect is also observed in this path (0.30). Thus, the same argument could be observed for the indirect and direct effects.

After further analysis, it was found that Thai Generation Y's environmental concern positively and significantly affects its environmental knowledge. Furthermore, other paths estimated in the model seem to have the same result, i.e., a positive and significant coefficient. In other words, the results from the SEM estimation support all the nine hypotheses of this study. One noteworthy finding could be that environmental knowledge has the least direct effect on purchasing intention (0.19). On the other hand, attitude towards green packaging seems to affect purchasing intention directly. However, the highest total effect on purchasing intention seems to belong to green marketing awareness, 
which goes through attitude towards green packaging. In other words, given the findings of this study, the most effective method for convincing Thai people to buy green products would be through green packaging.

\section{Theoretical and Practical Implications}

This study focused on the key factors affecting Thai Generation Y's behavior towards the greenness of personal care products. In order to do so, the data gathered from a structured questionnaire was analyzed through the SEM estimation. The study pays extra attention to those between 20 to 40 years of age (Generation Y). The reason behind this decision is the special awareness that Generation $Y$ has shown concerning environmental issues. Given the model's results, one key implication would be the importance of packaging in Thai people's behavior towards greenness of personal care. Contrary to Hayat et al. [43], who claim price sensitivity to be a key influential factor in consumers' behavior towards green products, the current study's findings show that packaging's influence outweighs the effects of price considerably. Furthermore, despite what Li et al. [20] argue, this study shows that simply being concerned about the environment is not enough incentive to purchase eco-friendly products.

Moreover, the relatively low coefficient of green price sensitivity combined with the fact that more than 80 percent of the subjects were students, or wage earners, and more than 70 percent of the subjects earned less than $\$ 833$ per month, implies that for Thai Generation $\mathrm{Y}$, greenness is much more important than the price of the product and the burden it puts on their budget. In other words, greenness is more of a necessity than a luxury to them. Therefore, to incentivize them into buying a product, the producer needs to find a way to assure them of its greenness; given the findings of this study, the packaging seems to be the optimum way to do so.

\section{Discussions, Conclusions and Suggestions for Future Studies}

This study aimed to assess and evaluate the factors affecting the consumers' behavior towards green products. In order to do so, this study analyzed the purchasing intention of Generation Y in Thailand. The reason for choosing Generation Y was because they are quite familiar with technology, which makes them modern; on the other hand, they still have some connections to their traditions, which makes them traditional. In other words, Generation $Y$ seems to be a good representative of the past and the future. The products under study here belong to personal care products with a considerable share in Generation Y's consumption. Furthermore, given the considerable increase in the market for personal care products in Thailand and the high share of Generation Y's population, the study was conducted in Thailand. The data were gathered via a structured questionnaire which was extrapolated from past studies.

Environmental awareness, environmental knowledge, attitude towards green packaging, green price sensitivity, green marketing awareness, and purchasing intention among Generation $\mathrm{Y}$ in Thailand were assessed. The main dependent variable in this study was purchasing intention, and the effects of the other variables on it were assessed using the structural equation model. The results showed significant and positive effects on purchasing intentions, with environmental concern and green price sensitivity having the least, and attitude towards green packaging and green marketing awareness having the most effect on purchasing intention for green products $[60,61]$.

Although environmental knowledge significantly affects purchasing intention, it is stronger through attitude towards green packaging. In other words, knowledge of environmental issues requires some physical trigger to turn into action. As the results suggest, the physical trigger for environmental knowledge to turn into action (purchasing intention) is the attitude towards green packaging. Moreover, they together become the physical trigger for environmental concern's manifestation in terms of purchasing intention. This finding has both practical and theoretical implications. Given the findings of this study, the packaging is the most effective tool at the producer's disposal to influence consumers. 
Furthermore, the findings suggest the importance of perception in the decision-making process of consumers. This study, therefore, could become the first step towards more comprehensive consumer theories.

Regarding practical implications, the results suggest the significance of packaging in forming purchasing intentions. This in turn suggests that while different approaches could persuade consumers in paying extra to purchase eco-friendly products instead of their alternatives, they require some sort of assurance. The results suggest packaging to be this agent of assurance. Therefore, the producers are encouraged to pay more attention on how they represent the green side of their products on their packaging. This could be reaffirmed through several rounds of focus groups with the Y-generation as the main members.

Considering theoretical implications, the results could act as a first step in supplementing consumer theory. As discussed in the early sections of the paper, consumer theory is somewhat silent on the intangible and mental aspects of consumer behavior. However, there are some theories in social psychology such as the theory of planned behavior that could help in explaining the mental aspect of consumer behavior. Although, this paper is the result of an empirical study, the findings support the existence of intangible factors affecting consumer's behavior. Therefore, the next step could be combining mental factors with material factors in a partial equilibrium to provide a more robust theoretical background for further studies.

Similar to other studies, this study has several limitations, which opens the door for further studies. First, the questionnaire used in this study was extracted from some other studies from the past. Although the due diligence has been made here and the results are quite reliable, the time for an original questionnaire based on a comprehensive qualitative method is long overdue. Second, this study focused on the demand section of the market for green products. Therefore, studying the value chain in the supply section of the market for green products could serve as a desirable complement for the current study. Finally, this study is an empirical one which limits its theoretical reach. In other words, the next step which the authors recommend would be devising a partial equilibrium analysis to provide a more consistent basis for further studies.

Author Contributions: Conceptualization, M.M., P.C. and S.F.; methodology, M.M. and P.C.; software, M.M., P.C. and S.F.; validation, M.M., S.F. and W.-K.W.; formal analysis, M.M.; investigation, P.C.; resources, M.M., W.-K.W.; data curation, M.M., and P.C.; writing-original draft preparation, M.M. and P.C.; writing-review and editing, S.F. and W.-K.W.; visualization, P.C.; supervision, M.M.; project administration, M.M.; funding acquisition, M.M. and W.-K.W. All authors have read and agreed to the published version of the manuscript.

Funding: This research received no external funding.

Institutional Review Board Statement: Not applicable. This study did not involve any harm to humans or animals. Data collection was anonymous.

Informed Consent Statement: Not applicable.

Data Availability Statement: Not applicable.

Conflicts of Interest: We declare that this study does not have any conflict of interest.

\section{References}

1. Chen, T.B.; Chai, L.T. Attitude towards the environment and green products: Consumers' perspective. Manag. Sci. Eng. 2010, 4, 27-39.

2. Panahi, M.; Keivandarian, A.; Azizi, A. Investigating the Consumer Attitude toward Green Marketing. Eur. J. Bus. Manag. 2014, 6, 1-6.

3. Prakash, G.; Pathak, P. Intention to buy eco-friendly packaged products among young consumers' of India: A study on developing nation. J. Clean. Prod. 2017, 141, 385-393. [CrossRef]

4. Pino, G.; Peluso, A.M.; Guido, G. Determinants of Regular and Occasional Consumers' Intentions to Buy Organic Food. J. Consum. Aff. 2012, 46, 157-169. [CrossRef]

5. Kumar, A.; Prakash, G.; Kumar, G. Does environmentally responsible purchase intention matter for consumers? A predictive sustainable model developed through an empirical study. J. Retail. Consum. Serv. 2021, 58, 102270. [CrossRef] 
6. Ghazali, E.; Soon, P.C.; Mutum, D.S.; Nguyen, B. Health and cosmetics: Investigating consumers' values for buying organic personal care products. J. Retail. Consum. Serv. 2017, 39, 154-163. [CrossRef]

7. Ameri Research Inc. Global Organic Personal Care Market Outlook to 2025. 6 September 2018. Available online: https: //www.ameriresearch.com/product/organic-personal-care-market/ (accessed on 22 September 2021).

8. Administration, T.I. Personal Care and Beauty Products. 13 October 2019. Available online: https://www.trade.gov/knowledgeproduct/thailand-personal-care-and-beauty-products (accessed on 22 September 2021).

9. Funatsu, T. Part II the case of Thailand: 8 Environmental awareness in Thailand: "Institutonalization" of environmental problems and the state of the save-nature boom. In Environmental Awareness in Developing Countries; Institute of Developing Economies: Chiba, Japan, 1997; pp. 169-177.

10. Orzan, G.; Cruceru, A.F.; Teodora, C.; Chivu, R. Consumers' Behavior Concerning Sustainable Packaging: An Exploratory Study on Romanian Consumers. Sustainability 2018, 10, 1787. [CrossRef]

11. Yadav, R.; Pathak, G.S. Green marketing: Initiatives in the Indian context. Indian J. Mark. 2013, 43, 25-32. [CrossRef]

12. Thailand Board of Investment. Thailand in Brief. 2021. Available online: https://www.boi.go.th/index.php?page=demographic (accessed on 22 September 2021).

13. Noorhazila, N.; Mud, N.; Nadia, A.; Zakaria, I.; Mahat, N.A. Consumer Awareness of Using Eco-friendly Packaging Product Among Generation X in Kota Bharu, Kelantan. Int. J. Acad. Res. Bus. Soc. Sci. 2018, 8, 1463-1472.

14. Anastasios, P.; Athanasios, K.K. Green Consumption Behavior Antecedents: Environmental Concern, Knowledge, and Beliefs. Psychol. Mark. 2014, 31, 335-348.

15. Wu, S.; Chen, Y. The Impact of Green Marketing and Perceived Innovation on Purchase Intention for Green Products. Int. J. Mark. Stud. 2014, 6, 81-100. [CrossRef]

16. Rahmi, D.Y.; Rozalia, Y.; Chan, D.N.; Anira, Q.; Prima, R. Green Brand Image Relation Model, Green Awareness, Green Advertisement, Green brand image, green awareness, green advertisement, and ecological knowledge in improving green purchase intention and green purchase behavior on creative industry products. J. Econ. Bus. Account. Ventur. 2017, 20, 177-186.

17. Ajzen, I. From intentions to actions: A theory of planned behavior. In Action Control; Springer: Berlin/Heidelberg, Germany, 1985; pp. 11-39.

18. Homer, P.M.; Kahle, L.R. A structural equation test of the value-attitude-behavior hierarchy. J. Pers. Soc. Psychol. 1988, 54, 638-646. [CrossRef]

19. Varian, H.R. Intermediate Microeconomics with Calculus: A modern Approach; WW Norton \& Company: New York, NY, USA, 2014.

20. Keynes, J.M. The General Theory of Employment, Interest, and Money; Springer: Berlin/Heidelberg, Germany, 2018.

21. Modigliani, F. The life cycle hypothesis of saving, the demand for wealth and the supply of capital. Soc. Res. 1966, 33, 160-217.

22. Palley, T.I. The Relative Income Theory of Consumption: A Synthetic Keynes-Duesenberry-Friedman Model; Political Economy Research Institute: Boston, MA, USA, 2008.

23. North, D.C. Institutional change: A framework of analysis. In Social Rules; Routledge: London, UK, 2018 ; pp. $189-201$.

24. Li, G.; Li, W.; Jin, Z.; Wang, Z. Influence of Environmental Concern and Knowledge on Households' Willingness to Purchase Energy-Efficient Appliances: A Case Study in Shanxi, China. Sustainability 2019, 11, 1073. [CrossRef]

25. Molinillo, S.; Vidal-Branco, M.; Japutra, A. Understanding the drivers of organic foods purchasing of millennials: Evidence from Brazil and Spain. J. Retail. Consum. Serv. 2020, 52, 101926. [CrossRef]

26. Naderi, I.; Van Steenburg, E. Me first, then the environment: Young Millennials as green consumers. Young Consum. 2019, 19, 280-295. [CrossRef]

27. Kim, H.Y.; Chung, J. Consumer purchase intention for organic personal care products. J. Consum. Mark. 2011, 28 , 40-47.

28. Lee, Y.K. A Comparative Study of Green Purchase Intention between Korean and Chinese Consumers: The Moderating Role of Collectivism. Sustainability 2017, 9, 1930. [CrossRef]

29. Bang, H.-K.; Ellinger, A.; Hadjimarcou, J.; Traichal, P.A. Consumer concern, knowledge, belief, and attitude toward renewable energy: An application of the reasoned action theory. Psychol. Mark. 2000, 17, 449-468. [CrossRef]

30. Rajendran, S.; Wahab, S.N.; Kaur, M. Malaysian consumers' preference for green packaging Malaysian consumers' preference for green packaging. Int. J. Soc. Syst. Sci. 2019, 11, 312-328. [CrossRef]

31. Maheshwari, S.P. Awareness of Green Marketing and Its Influence on Buying Behavior of Consumers: Special Reference to Maghya Pradesh, India. AIMA J. Manag. Res. 2014, 0974-497.

32. Zaremohzzabieh, Z.; Ismail, N.; Ahrari, S.; Abu Samah, A. The effects of consumer attitude on green purchase intention: A meta-analytic path analysis. J. Bus. Res. 2020, 132, 732-743. [CrossRef]

33. Yang, Y.; Asaad, Y.; Dwivedi, Y. Examining the impact of gamification on intention of engagement and brand attitude in the marketing context. Comput. Hum. Behav. 2017, 73, 459-469. [CrossRef]

34. Laksamana, P. Impact of Social Media Marketing on Purchase Intention and Brand Loyalty: Evidence from Indonesia's Banking Industry. Int. Rev. Manag. Mark. 2018, 8, 13-18.

35. Martins, J.; Costa, C.; Oliveira, T.; Gonçalves, R.; Branco, F. How smartphone advertising influences consumers' purchase intention. J. Bus. Res. 2019, 94, 378-387. [CrossRef]

36. Kusuma, P.N.P.D.; Sulhaini, R.B.H. The Effect of Environmental Knowledge, Green Advertising, and Environmental Attitude toward Green Purchase Intention. Russ. J. Agric. Socio-Econ. Sci. 2018, 78, 95-105. 
37. Hsu, C.-L.; Chang, C.-Y.; Yansritakul, C. Exploring purchase intention of green skincare products using the theory of planned behavior: Testing the moderating effects of country of origin and crossmark price sensitivity. J. Retail. Consum. Serv. 2017, 34, 145-152. [CrossRef]

38. Layard, P.R.G.; Walters, A.A. Microeconomic Theory; McGraw-Hill Companies: New York, NY, USA, 1978.

39. Gao, H.; Zhang, Y.; Mittal, V. How Does Local-Global Identity Affect Price Sensitivity? J. Mark. 2017, 81, 62-79. [CrossRef]

40. Homburg, C.; Hoyer, W.D.; Koschate, N. Customers' Reactions to Price Increases: Do Customer Satisfaction and Perceived Motive Fairness Matter? J. Acad. Mark. Sci. 2005, 33, 36-49. [CrossRef]

41. Arnett, J.J. The psychology of globalization. Am. Psychol. 2002, 57, 774-783. [CrossRef] [PubMed]

42. Ghali-Zinoubi, Z.; Toukabri, M. The antecedents of the consumer purchase intention: Sensitivity to price and involvement in organic product: Moderating role of product regional identity. Trends Food Sci. Technol. 2019, 90, 175-179. [CrossRef]

43. Jan, I.U.; Ji, S.; Yeo, C. Values and Green Product Purchase Behavior: The Moderating Effects of the Role of Government and Media Exposure. Sustainability 2019, 11, 6642. [CrossRef]

44. Auliandri, T.A.; Thoyib, A.; Fatchur, R.; Ainur, R. Does Green Packaging Matter as a Business Strategy? Exploring Young Consumers' Consumption in an Emerging Market. Probl. Perspect. Manag. 2018, 16, 376-384. [CrossRef]

45. Maichum, K.; Surakiat, P.; Peng, K.-C. Factors Affecting on Purchase Intention towards Green Products: A Case Study of Young Consumers in Thailand. Int. J. Soc. Sci. Humanit. 2017, 7, 330-335.

46. Sethi, V. Determining Factors of Attitude towards Green Purchase Behavior of FMCG Products. IITM J. Manag. IT 2018, 9, 10-25.

47. Trivedi, R.H.; Patel, J.; Acharya, N. Causality analysis of media influence on environmental attitude, intention and behaviors leading to green purchasing. J. Clean. Prod. 2018, 196, 11-22. [CrossRef]

48. Yadav, R.; Pathak, G.S. Young consumers' intention towards buying green products in a developing nation: Extending the theory of planned behavior. J. Clean. Prod. 2016, 135, 732-739. [CrossRef]

49. Koenig-Lewis, N.; Palmer, A.; Dermody, J. Consumers' evaluations of ecological packaging-Rational or emotional? J. Environ. Psychol. 2014, 37, 94-105. [CrossRef]

50. Suki, N.M.; Azman, N.S. Impacts of Corporate Social Responsibility on the Links Between Green Marketing Awareness and Consumer Purchase Intentions. Procedia Econ. Financ. 2016, 37, 262-268. [CrossRef]

51. Paul, L.C.; Suman, A.A.; Sultan, N. Methodological Analysis of Principal Component Analysis (PCA) Method. IJCEM Int. J. Comput. Eng. Manag. 2013, 16, 32-37.

52. Worldometer. Thailand Population. 2020. Available online: https://www.worldometers.info/world-population/thailandpopulation/ (accessed on 22 September 2021).

53. Podsakoff, P.M.; Organ, D.W. Self-Reports in Organizational Research: Problems and Prospects. J. Manag. 1986, 12, 531-544. [CrossRef]

54. Cochran, W.G. Note on an Approximate Formula for the Significance Levels of Z. Ann. Math. Stat. 1940, 11, 93-95. [CrossRef]

55. Cronbach, L.J. Coefficient alpha and the internal structure of tests. Psychometrika 1951, 16, 297-334. [CrossRef]

56. Bagozzi, R.P.; Yi, Y. On the evaluation of structural equation models. J. Acad. Mark. Sci. 1988, 16, 74-94. [CrossRef]

57. Brown, M.W.; Cudeck, R. Alternative ways of assessing model fit. In Testing Structural Equation Models; Bollen, K.A., Long, J.S., Eds.; Sage: Beverly Hills, CA, USA, 1993; pp. 111-135.

58. Fornell, C.; Larcker, D.F. Structural equation models with unobservable variables and measurement error: Algebra and statistics. J. Mark. Res. 1981, 3, 382-388. [CrossRef]

59. de Winter, J.; Dodou, D.; Wieringa, P.A. Exploratory Factor Analysis with Small Sample Sizes. Multivar. Behav. Res. 2009, 44, 147-181. [CrossRef] [PubMed]

60. Jianming, W.; Linh, P.T.; Thac, D.V. Environmental Consciousness and Organic Food Purchase Intention: A Moderated Mediation Model of Per-ceived Food Quality and Price Sensitivity. Int. J. Environ. Res. Public Health 2020, 17, 850. [CrossRef]

61. López-Fernández, A.M. Price sensitivity versus ethical consumption: A study of Millennial utilitarian consumer behavior. J. Mark. Anal. 2020, 8, 57-68. [CrossRef] 